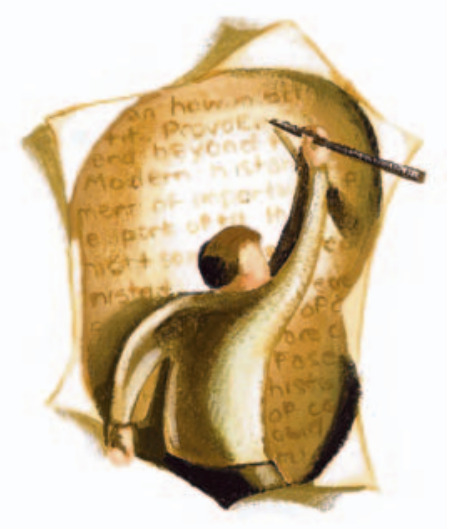

\section{Enhancing research}

\section{integrity}

Wayne Kondro and Paul Hébert advocate establishing a central agency in Canada to deal with scientific misconduct. ${ }^{1}$ We propose a set of preventive procedures to enhance research integrity. Researchers should consider the US Sarbanes-Oxley Act of 2002, ${ }^{2}$ which was enacted following several corporate accounting scandals. Although some claim that the Sarbanes-Oxley Act is intrusive, expensive and heavy-handed, it has proven useful for preventing accounting fraud. ${ }^{3}$ We believe that its provisions can also be applied to scientific research in 4 ways.

First, the legislation requires companies to have a complete set of internal controls. Research organizations should develop internal depositories for all data and should document the processes, analytic procedures and research methodologies their researchers use; all of the resulting material should be audited by external bodies.

Second, companies are required to have corporate officers who are personally responsible for the accuracy of financial statements. In a similar way, each research organization should have a designated "accountable scientist" responsible for research integrity.

Third, generally accepted auditing standards specify the requirements for assessing a company's financial statements. ${ }^{4}$ Similar standards are needed for the peer review process, which currently varies widely. Furthermore, the peer review process should be accredited. This would include assessing the performance of peer reviewers with blinded reviews of specially prepared articles. For instance, the Proficiency Testing Program for Mineral Analysis Laboratories offers a means by which laboratories can assess their performance independently of internal quality control. ${ }^{5}$

Finally, the requirement for internal financial controls prevents fraudulent transactions. Plagiarism is a related issue. International systems to detect scientific plagiarism could be rapidly implemented by using as a template the automated systems presently used by colleges and universities to detect plagiarism in student assignments.

\section{Vincent V. Richman PhD}

Professor of Accounting

School of Business and Economics

Sonoma State University

Rohnert Park, Calif.

Alex Richman MD

Adjunct Professor

Faculty of Management

Dalhousie University

Halifax, NS

Competing interests: None declared.

\section{REFERENCES}

I. Kondro W, Hébert PC. Research misconduct? What misconduct? CMAJ 2007;176(7):905.

2. Sarbanes Oxley ror: info guide to the SarbanesOxley Act of 2002. 2006. Available: www.sarbanes -oxley-IoI.com (accessed 2007 Jun 30).

3. Finance and economics: darned SOX. Reaction to Sarbanes-Oxley. Economist 2006;380(8495):98.

4. Generally accepted auditing standards. Available: www.answers.com/topic/generally-accepted-auditing -standards (accessed 2007 Jun 30).

5. Proficiency Testing Program for Mineral Analysis Laboratories. Ottawa: Natural Resources Canada; 2007. Available: www.nrcan.gc.ca/ms/canmet-mtb /mmsl-lmsm/ccrmp/ptp/visitors.htm (accessed 2007 Jun 30).

DOI:I0.1503/cmaj.1070059

\section{Ethical funds for physicians}

CMA Holdings Inc. has a policy of not investing in the tobacco industry. This is admirable and to be expected from a physician-owned corporation. I also believe that, as a matter of policy, CMA
Holdings and its subsidiary MD Management Ltd. should not invest in companies that manufacture weapons.

Physicians busy with medical practice and family usually do not take the time required to learn in detail what corporations they are investing in. A physician's first responsibility is to do no harm. Investing in companies whose products' only purpose is to kill and injure people would seem to be a conflict of interest for physicians. I recently wrote to the CMA President, Colin McMillan, suggesting that it was time for MD Management to develop and promote an ethical fund for physician investment; the Saskatchewan Medical Association has made a similar request. ${ }^{1}$ I hope that my medical colleagues who agree that MD Management should not be investing in arms manufacturers will let their MD Management financial advisors, Brian Peters (President and Chief Executive Officer of CMA Holdings) and McMillan know their position on this matter.

\section{David J. Beaudin MD \\ Gastroenterologist \\ Saint John Regional Hospital \\ Saint John, NB}

Competing interests: None declared.

\section{REFERENCE}

I. Eggertson L. More calls for ethical investing. CMAJ 2007;176(9):1266-7.

DOI:I0.1503/cmaj.1070038

\section{Canada's approach}

\section{to conflict-of-interest}

\section{oversight}

In his $C M A J$ news piece on the proposed US Food and Drug Administration conflict-of-interest rules that would limit the ability of experts with financial interests in the pharmaceutical industry to sit on the agency's advisory committees, Wayne Kondro highlighted the lack of similar rules in Canada. ${ }^{1}$ However, recent policy trends 
indicate that Canada is taking a more restrictive approach by banning experts with nonfinancial conflicts of interest from similar advisory and oversight committees. For example, Canada's Assisted Human Reproduction Act precludes people licensed to conduct human embryonic stem cell research, or potential licensees, from serving on the Board of Directors of the Assisted Human Reproduction Agency. This rule was severely criticized following the exclusion of stem cell scientists and fertility experts from the agency's recently constituted board. ${ }^{2}$ Likewise, the Canadian Institutes of Health Research exclude researchers affiliated with Canada's Stem Cell Network from membership in the Stem Cell Oversight Committee, the national stem cell research ethics board.

This move toward a more restrictive regulatory regime is different from the approach used in other jurisdictions. For example, in California, stem cell research oversight committees can include members with relevant expertise. Similarly, fertility clinicians and human embryonic stem cell research scientists are allowed to be members of the $\mathrm{Hu}$ man Embryology and Fertilisation Authority, the body responsible for overseeing embryo research in the United Kingdom. A recent study of UK fertility clinic patients found "overwhelming support for doctors to be the most important members of the Authority, followed by researchers working in the area." ${ }^{3}$ Both jurisdictions manage conflicts of interest in advisory committees through strategies such as disclosure or divestment of conflicting interests and exclusion of experts from committee leadership roles.

It could be argued that the Canadian rules outlined above are specific to stem cell research and may very well be the result of Canadians' desire for strict regulation of emerging biotechnologies. ${ }^{4,5}$ However, conflicts of interest in stem cell research committees have not been shown to be qualitatively different from those in other scientific advisory and oversight contexts. Until there is such evidence to the contrary, the policy response to conflicts of interest should focus on addressing the need for specific expertise on these commit- tees with effective management strategies, such as disclosure and divestment of financial interests.

\section{Ubaka Ogbogu LLM \\ Health Law Institute \\ University of Alberta \\ Edmonton, Alta.}

Competing interests: None declared.

\section{REFERENCES}

I. Kondro W. US proposes more stringent conflictof-interest rules. $C M A J$ I76(II):157I-2.

2. Abraham C. Critics troubled by new fertility panel. Globe and Mail 2006 Dec 23; Sect A:I.

3. Callus T. Patient perceptions of the Human Fertilisation and Embryology Authority. Med Law Rev 2007;15(I):62-85.

4. Pollara Research and Earnscliffe Research and Communications. Public opinion research into biotechnology issues: executive summary, fifth wave. Ottawa: Canadian Biotechnology Secretariat; 200I. Available: www.biostrategy.gc.ca/CMFiles 15Wavexec-e49RWH-922004-8008.pdf (accessed 2007 Jun 29).

5. Pollara Research and Earnscliffe Research and Communications. Public opinion research into biotechnology issues: executive summary, sixth wave. Ottawa: Canadian Biotechnology Secretariat; 2002. Available: www.biostrategy.gc.ca/CMFiles /W6ExSum49RWZ-922004-6944.pdf (accessed 2007 Jun 29).

DOI:I0.1503/cmaj.1070077

\section{Is primary care a lost cause?}

The difficulty in attracting graduating physicians to family practice that Wayne Kondro described in a recent $C M A J$ news piece $^{1}$ is a worldwide phenomenon. ${ }^{2}$ In $1987,31 \%$ of German medical students wanted to become family physicians, whereas in 1995 only $9 \%$ of medical students at the University of Göttingen made this career choice ${ }^{3}$; in 2006 fewer than $4 \%$ of medical students at the University of Leipzig chose family medicine. ${ }^{4}$

Among the many factors influencing specialty choice, ${ }^{5}$ one that can be easily altered to improve the appeal of family medicine to students is the set of state or professional regulations that govern the process of qualifying to become a general practitioner. In most parts of Europe it takes 3 years of training to qualify for a general practice licence. However, in Germany there have been 3 different routes to licensure for general practitioners over the past decade, requiring training periods ranging from 3 to 5 years. This lack of consistency has had dramatic consequences in terms of shortages of family physicians; young physicians have been deterred from entering family practice in Germany because of the uncertainty associated with frequent changes in the regulations governing the clinical training periods and seminars on medical theory that are required to obtain licensure as a family physician.

Postgraduate education and the routes to licensure for family practitioners have been reformed almost continuously over the past decade in Germany in the spirit of quality improvement. However, when access to training in general practice was restricted in Germany at one point, a severe shortage of family physicians resulted. Many young Germans chose an alternative medical career (e.g., in general internal medicine) or went to countries with more relaxed and stable regulations, such as Switzerland and Australia.

\section{Hagen Sandholzer MD PhD \\ Professor and Head \\ Department of Family Medicine \\ University of Leipzig \\ Leipzig, Germany}

Competing interests: None declared.

\section{REFERENCES}

I. Kondro W. Family practice a tough sell. $C M A J$ 2007;I76(II):I570-I.

2. Kidd MR. Is general practice vocational training at risk? Med J Aust 2003;179:I6-7.

3. Sandholzer H, Scheer N, Kochen MM. Is family medicine dying? Results of a survey among medical students. Z Allgemeinmed I997;73:9.

4. Sandholzer H. Lessons learned from ro years of discussion on general practice vocational training. Notfall Hausarztmedizin 2007;33:227.

5. Bland CJ, Meurer LN, Maldonado G. Determinants of primary care specialty choice: a non-statistical meta-analysis of the literature. Acad Med 1995;70: 620-4I.

DOI:I0.1503/cmaj.1070078

\section{Sleepy older drivers}

Norman Wolkove and colleagues recently presented an excellent review of sleep disorders in older people. ${ }^{1,2}$ However, they did not mention that one of the main symptoms of sleep disorders, excessive daytime sleepiness, increases the risk of automobile accidents. ${ }^{3}$ Primary caregivers should be aware that 